\title{
Spatial rainfall variability and runoff response during an extreme event in a semi-arid catchment in the South Pare Mountains, Tanzania
}

\author{
M. L. Mul ${ }^{1}$, H. H. G. Savenije ${ }^{2,1}$, and S. Uhlenbrook ${ }^{1,2}$ \\ ${ }^{1}$ UNESCO-IHE Institute for Water Education, Delft, Westvest 7, P.O. Box 3015, 2601 DA Delft, The Netherlands \\ ${ }^{2}$ Water Resources Section, Faculty of Civil Engineering and Applied Geosciences, Delft University of Technology, Stevinweg \\ 1, P.O. Box 5048, 2600 GA Delft, The Netherlands
}

Received: 1 August 2008 - Published in Hydrol. Earth Syst. Sci. Discuss.: 9 September 2008

Revised: 21 July 2009 - Accepted: 3 September 2009 - Published: 18 September 2009

\begin{abstract}
This paper describes an extreme flood event that occurred in the South Pare Mountains in northern Tanzania. A high spatial and temporal resolution data set has been gathered in a previously ungauged catchment. This data was analysed using a multi-method approach, to gather information about the processes that generated the flood event. On 1 March 2006, extreme rainfall occurred in the Makanya catchment, $\left(300 \mathrm{~km}^{2}\right)$, where up to $100 \mathrm{~mm}$ were recorded in Bangalala village in only $3 \mathrm{~h}$. The flood was devastating, inundating large parts of the flood plain. The spatial variability of the rainfall during the event was very large, even in areas with the same altitude. The Vudee sub-catchment $\left(25.8 \mathrm{~km}^{2}\right)$ was in the centre of the rainfall event, receiving about $75 \mathrm{~mm}$ in $3 \mathrm{~h}$ divided over the two upstream tributaries: the UpperVudee and Ndolwa. The peak flow at the weir site has been determined using the slope-area method and gradually varied flow calculations, indicating a peak discharge of $32 \mathrm{~m}^{3} \mathrm{~s}^{-1}$. Rise and fall of the flood was very sharp, with the peak flow occurring just one hour after the peak of the rainfall. The flow receded to $1 \%$ of the maximum flow within $24 \mathrm{~h}$. Hydrograph separation using hydrochemical parameters indicates that at the floodpeak $50 \%$ of the flow was generated by direct surface runoff (also indicated by the large amount of sediments in the samples), whereas the recession originated from displaced groundwater $(>90 \%)$. The subsequent base flow in the river remained at $751 \mathrm{~s}^{-1}$ for the rest of the season, which is substantially higher than the normal base flow observed during the previous rainy seasons $\left(151 \mathrm{~s}^{-1}\right)$ indicating significant groundwater recharge during this extreme event.
\end{abstract}

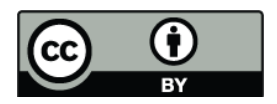

Correspondence to: M. L. Mul (m.mul@unesco-ihe.org)

\section{Introduction}

Monitoring networks around the world are in decline; particularly in sub-Saharan Africa, this is related to lack of financial resources and capacity (Mazvimavi, 2003). The IAHS has initiated the decade on "Predictions in Ungauged Basin" (PUB) (Sivapalan et al., 2003) that supports research focused on increasing capacity to predict hydrological responses in ungauged basins, particularly through increased process understanding, since intensifying the monitoring network is not possible in developing countries due to financial constraints.

This paper describes an extreme flood that occurred in the Makanya catchment on 1 March 2006, recorded with a relatively dense monitoring network, which is unique in subSaharan Africa. The high intensity network used temporarily for this study, should be seen as part of a multi-method experimental study to analyse the main runoff processes at play (Blume et al., 2008).

The flood analysed in this paper is one of the three big floods which were recently observed in Makanya village resulting from extreme rainfall events. These floods in December 2003, March 2006 and December 2007 caused damage to infrastructure and discontinuity of traffic on the main road and railroad due to overtopping. It appears that the impact of these events is increasing, whereby even houses were destroyed during the last event. Several causes can be identified, which could contribute to increased flooding downstream: land use changes from forest to agriculture (Calder, 1999; Sandström, 1995), changes in rainfall patterns (Mason et al., 1999) and sedimentation problems in the downstream river reach, due to erosion from upstream.

This paper aims to identify the origin of the 2006 flood and quantify the hydrological processes leading to this extreme

Published by Copernicus Publications on behalf of the European Geosciences Union. 


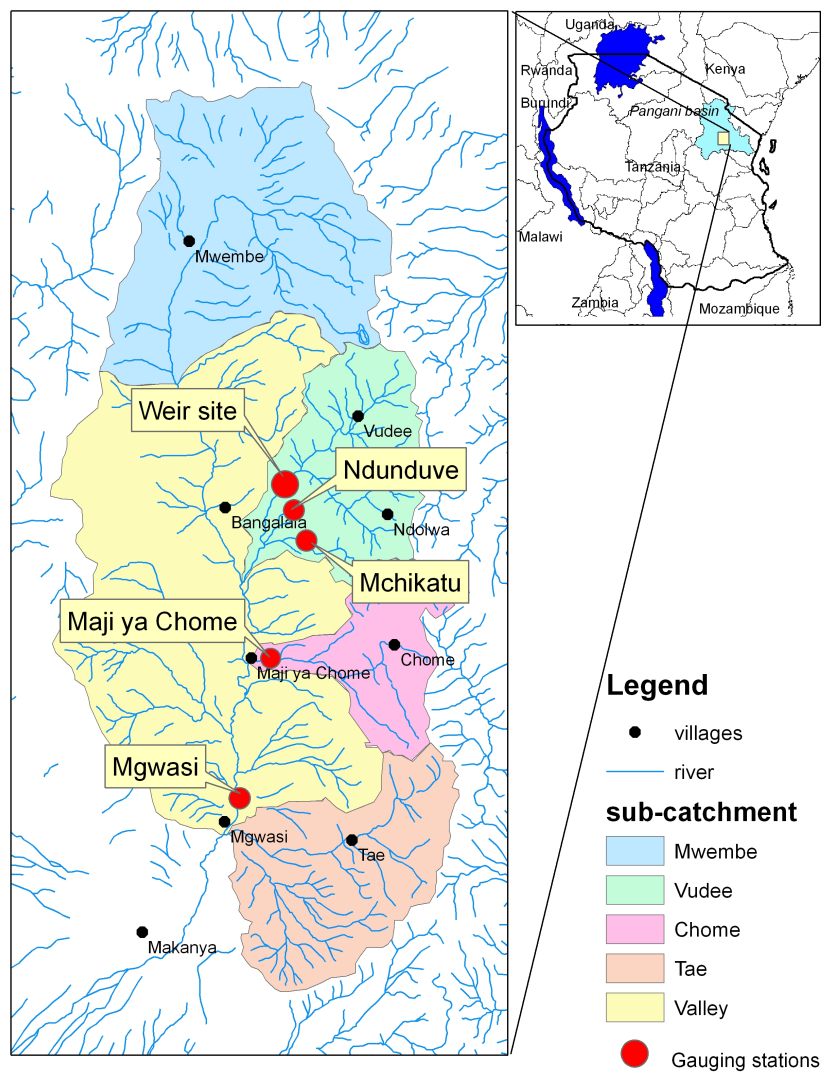

Fig. 1. Location of Makanya catchment and sub-catchments and instrumentation network.

event through a multi-method approach (Blume et al., 2008). This paper reconstructs the event, through the analysis of the spatial and temporal rainfall variability, the reconstruction of the discharge at different locations in the catchment and their time of concentration. Hydrograph separation was used to analyse the origin of the runoff.

\section{Study area}

The Makanya catchment is located in the South Pare Mountains in northern Tanzania and is a tributary to the Pangani River. The catchment area is approximately $300 \mathrm{~km}^{2}$ at the location of Makanya village. The altitude of the catchment ranges between 600 and more than $2000 \mathrm{~m}$. Four tributaries, i.e. Mwembe, Vudee, Chome and Tae, join the main stream in the Makanya catchment (Fig. 1), which only drains into the Pangani River during exceptionally large floods (SUA, 2003). The area experiences a bi-modal rainfall pattern, with the short rainy season occurring between November and January and the long rainy season occurring between March and May. The meteorological station in Same has rainfall records since 1934. During the short rainy season, locally called Vuli, it has an average rainfall amount of $208 \mathrm{~mm}$ season $^{-1}$ with a standard deviation of $140 \mathrm{~mm}$. Dur-
Table 1. Daily rainfall in the Makanya catchment, fallen on 1 March 2006, and return periods based on Same data (1934-2006, $882 \mathrm{~m}$ ).

\begin{tabular}{|c|c|c|c|c|c|}
\hline no & name & Altitude & $\begin{array}{l}\text { Rainfall } \\
\mathrm{mm} \mathrm{d}^{-1}\end{array}$ & $\begin{array}{c}\text { Return } \\
\text { Period } \\
\text { (annual) } \\
\text { yrs }\end{array}$ & $\begin{array}{c}\text { Return } \\
\text { Period } \\
\text { (seasonal) } \\
\text { yrs }\end{array}$ \\
\hline 1 & $\begin{array}{l}\text { Bangalala } \\
\text { automatic }\end{array}$ & 938 & 77.7 & 5.5 & 9.5 \\
\hline 2 & Vudee & 1396 & 60.6 & 2.5 & 3.5 \\
\hline 2 & $\begin{array}{l}\text { Vudee } \\
\text { automatic }\end{array}$ & 1396 & 82.1 & 7 & 13 \\
\hline 3 & Chani & 1306 & 9.3 & $<2$ & $<2$ \\
\hline 4 & Chome & 1664 & 122.5 & 67 & 195 \\
\hline 5 & Makanya & 640 & 56.4 & 2 & 3 \\
\hline 6 & Tae Malindi & 1741 & 106.0 & 26 & 64 \\
\hline 7 & Same & 882 & 0 & N/A & N/A \\
\hline 8 & Sisal Estate & 698 & 50.3 & $<2$ & 2 \\
\hline 9 & Ndolwa & 1554 & 82.7 & 7 & 14 \\
\hline 9 & $\begin{array}{l}\text { Ndolwa } \\
\text { automatic }\end{array}$ & 1544 & 77.5 & 5.5 & 9.5 \\
\hline 10 & Mchikatu & 885 & 114.2 & 41.5 & 110 \\
\hline 10 & $\begin{array}{l}\text { Mchikatu } \\
\text { automatic }\end{array}$ & 885 & 102.7 & 22 & 50 \\
\hline 11 & Wilson chini & 834 & 62.8 & 2.8 & 4 \\
\hline 12 & Eliza & 870 & 118.9 & 55 & 150 \\
\hline 13 & Mwembe & 975 & 15.0 & $<2$ & $<2$ \\
\hline 13 & $\begin{array}{l}\text { Mwembe } \\
\text { automatic }\end{array}$ & 975 & 15.4 & $<2$ & $<2$ \\
\hline 14 & Iddi & 960 & 14.2 & $<2$ & $<2$ \\
\hline
\end{tabular}

ing the long rainy season, locally called Masika, the average rainfall is $325 \mathrm{~mm} \mathrm{season}^{-1}$ with a standard deviation of $130 \mathrm{~mm}$ (Mul et al., 2006). The study area has been the focus of the SSI programme since 2004 (Bhatt et al., 2006; Rockström et al., 2004). Existing hydrological measurements consist of a nearby meteorological station in Same (approximately $15 \mathrm{~km}$ outside of the catchment) and two rainfall stations with 16 years of record inside the catchment (Tae Malindi and Sisal estate, see Table 1). The SSI programme installed several hydrological gauging stations inside the catchment, such as automatic raingauges, a meteorological station and discharge stations at different sites.

Population in the Makanya catchment is estimated to 35000 with a growth rate of $1.6 \%$ per year (URT, 2004). The majority of the population living in the catchment is dependent on agriculture for their livelihood (Mwamfupe, 2002). Increasing population density has increased the necessity for agricultural lands. As a result, in the upland areas steep slopes have been cleared from trees and are subsequently cultivated (Enfors and Gordon, 2007). Rainfall patterns have changed in the Pangani basin, with a decline in low rainfall intensities $\left(<10 \mathrm{~mm} \mathrm{~d}^{-1}\right)$ and increasing occurrences of high rainfall intensities of the last decade (Valimba, 2004). These 

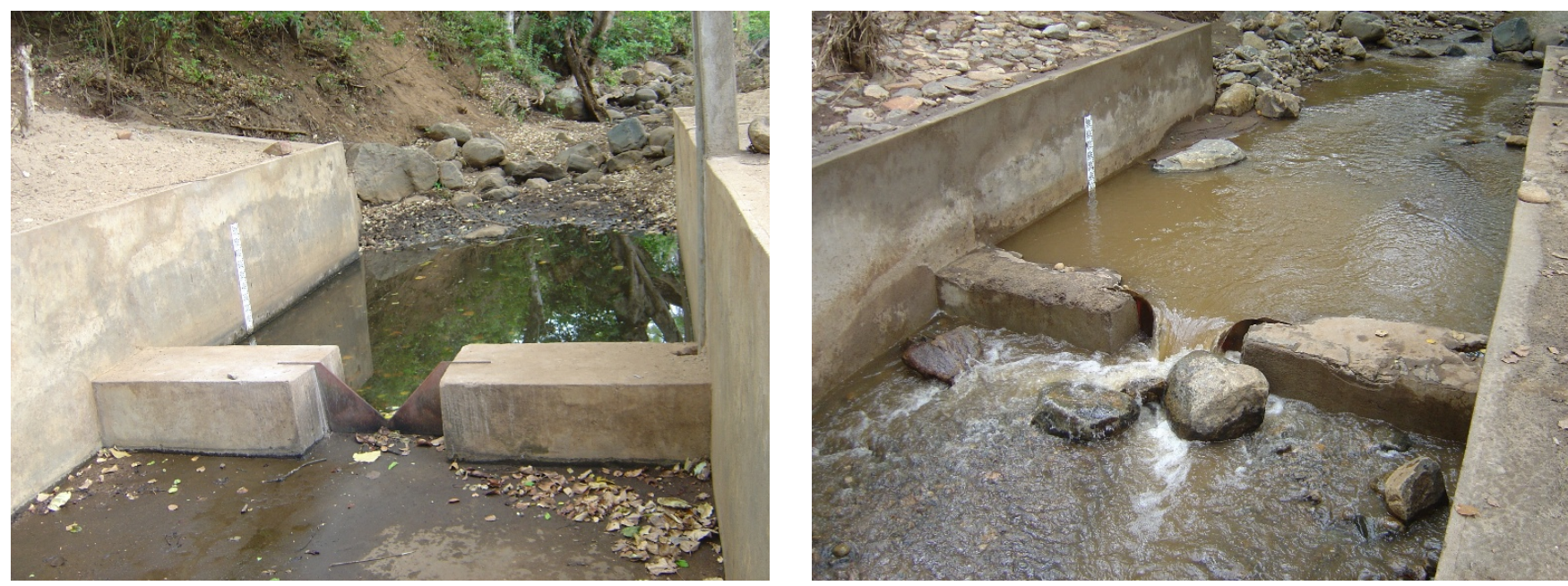

Fig. 2. The weir site in February 2006 (left) and March 2006 after the flood event (right).

changes make the catchment more vulnerable for floods. Understanding the generation of these floods provide further insights in how to overcome the impact of these floods.

\section{Multi-method approach}

The short rainy season of 2005/06 (October-January) preceding the flood was extremely dry, with a seasonal rainfall amount recorded in Same of $83 \mathrm{~mm}^{\text {season }}{ }^{-1}$, which is well below the long term average of $208 \mathrm{~mm} \mathrm{season}^{-1}$. At the weir site in Bangalala, the flow from Ndolwa and UpperVudee ceased completely, which according to local people happens only very rarely. However, this was observed earlier in 1948, 1974 and 1997 (Mul et al., 2006). Figure 2a shows the weir site during this period. Upstream water allocations can reduce the flow to zero, since upstream villages are allowed to abstract water during the day (Makurira et al., 2007). During the night; however, a small flow was observed at the weir site, when upstream villages were not abstracting water (Mul, 2009).

\subsection{Rainfall}

On 1 March, heavy rainfall was recorded in the catchment, resulting in excessive flooding at the downstream end of the catchment. Water levels during the peak of the flow overtopped the structure (level $>1.5 \mathrm{~m}$ ), transporting trees and big rocks, which damaged the V-notch and affected the pressure transducer post, as can be seen in the picture after the flood (Fig. 2b).

During the flood event in the Makanya catchment, rainfall was monitored at 14 locations, with hourly records at 5 locations and the remaining recorded daily rainfall at 9 a.m. every day.

\subsubsection{Daily rainfall}

The daily rainfall recorded in the catchment on 1 March 2006 ranged from 0 to $122 \mathrm{~mm} \mathrm{~d}^{-1}$ (Table 1). Figure 3 shows the spatial rainfall variability in the catchment based on inverse distance interpolation. In the most northern part of the catchment (altitude ranging from 950-1300 m), little rainfall was recorded (only $10-15 \mathrm{~mm} \mathrm{~d}^{-1}$ ). At Same village, $15 \mathrm{~km}$ from the catchment, no rainfall was recorded at all. In the highlands (altitude ranging from $1400-1750 \mathrm{~m}$ ), the rainfall recorded ranged from $75-120 \mathrm{~mm} \mathrm{~d}^{-1}$. The highest amount was recorded at Chome village as $122 \mathrm{~mm} \mathrm{~d}^{-1}$. In the midlands (altitude ranging around $800-900 \mathrm{~m}$ ) a similar high intensity rainfall was recorded, $60-120 \mathrm{~mm} \mathrm{~d}^{-1}$. In the lowlands, at Makanya village (altitude $650-700 \mathrm{~m}$ ), $50-60 \mathrm{~mm} \mathrm{~d}^{-1}$ was recorded. High intensity rainfall is not uncommon in the area, during the period of observation, in Same (lowlands), $15 \mathrm{~km}$ outside of the catchment area (1934-2006), 52 times rainfall of more than $50 \mathrm{~mm} \mathrm{~d}^{-1}$ was recorded with two instances of rainfall above $100 \mathrm{~mm} \mathrm{~d}^{-1}$. At Tae Malindi station for the recorded period (1990-2006) 8 times above $50 \mathrm{~mm} \mathrm{~d}^{-1}$ was recorded with one instance above $100 \mathrm{~mm} \mathrm{~d}^{-1}$ (this event, which is equal to the average monthly rainfall for March). At the sisal estate (1990-2006) 6 times rainfall above $50 \mathrm{~mm} \mathrm{~d}^{-1}$ was recorded.

Rainfall variability in the catchment cannot be explained solely by the topography. Areas with similar altitude, e.g. Mwembe and Bangalala in the midlands, differed by a factor of 5, and Chani and Vudee, located in the highlands, differed by a factor of 6-7. In general, it can be said that the storm passed through three out of four sub-catchments, namely Vudee, Chome and Tae. In the Vudee sub-catchment the highest rainfall was recorded in the valley, above $100 \mathrm{~mm} \mathrm{~d}^{-1}$, and in the upper parts of the catchment around $80 \mathrm{mmd}^{-1}$. In Chome and Tae 

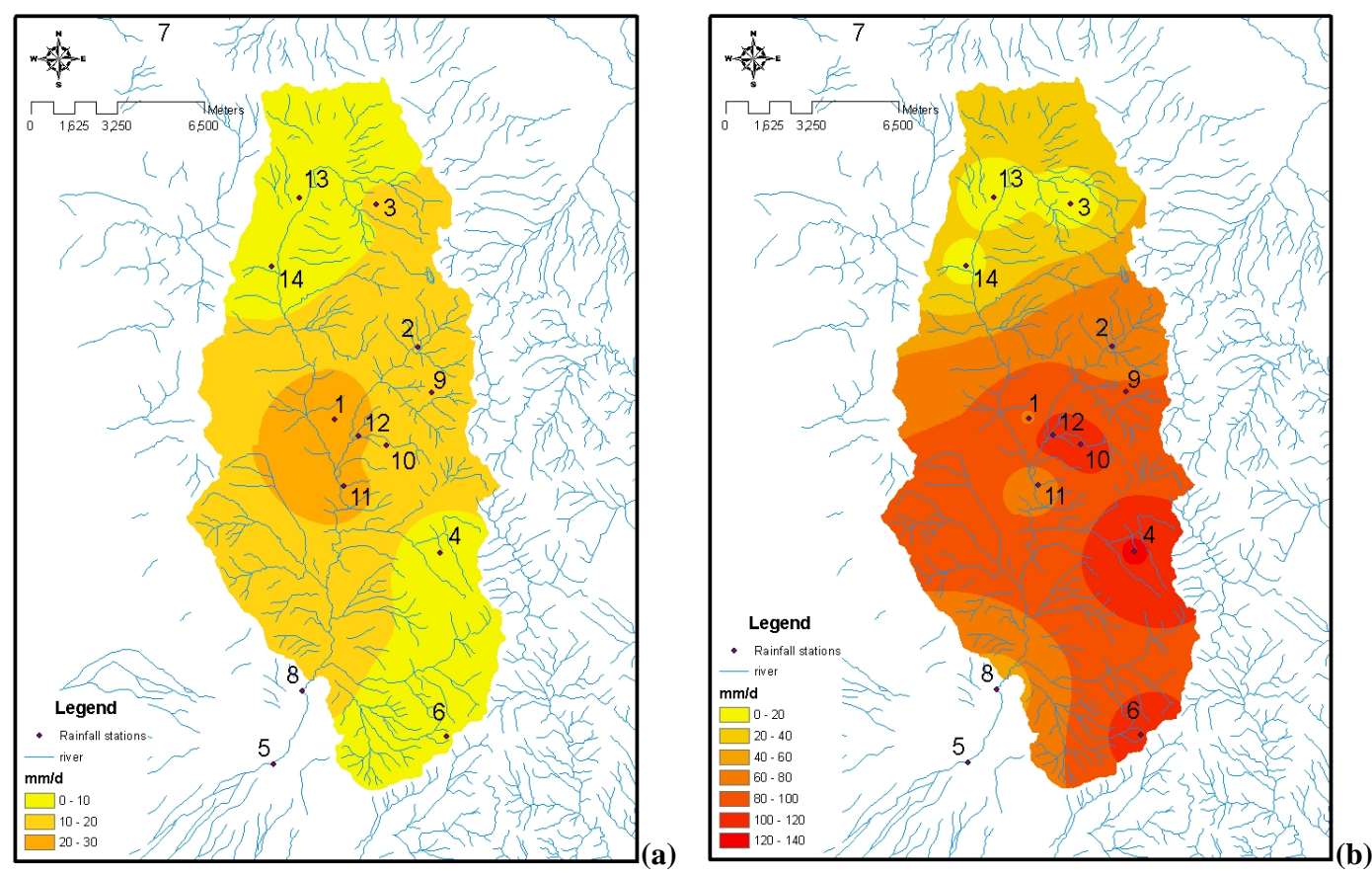

Fig. 3. Spatial rainfall variability on 28 February (a) and 1 March 2006 (b) in the Makanya catchment.

sub-catchments, the highest rainfall was recorded in the highlands, above $100 \mathrm{~mm} \mathrm{~d}^{-1}$, and in the midlands rainfall was around $50 \mathrm{~mm} \mathrm{~d}^{-1}$.

The highest intensity rainfall recorded during this event was of exceptional nature. Table 1 shows the return period of the rainfall event based on the only available long data set in Same (73 y) using SPELL-Stat (Guzman and Chu, 2003). The Gumbel distribution fitting has been used on the annual maximum daily rainfall events to obtain the return period of the observed rainfall. The highest intensities of the storm correspond to a return period of $67 \mathrm{y}$ (Chome, Table 1). Comparing the return period to the Gumbel distribution fitted on the seasonal (Masika) maximum daily rainfall gives an even more extreme picture, where the rainfall in Chome corresponds to a return period of $195 \mathrm{y}$ (Table 1). This is due to the fact that the sample size is smaller, and on top of that most high intensity rainfall events occur during the other rainy season (Vuli). It shows that intensities that were locally recorded have a very low probability of exceedence. It should be said that the data series that were used for the Gumbel distribution fitting were from a station outside of the catchment in the lowlands (altitude of $882 \mathrm{~m}$ ), therefore, the return periods serve only as an indication and are most probably overestimated.

\subsubsection{Hourly rainfall}

At five locations automatic rain gauges recorded the storm, centred around Vudee sub-catchment (Bangalala, Mchikatu,
Upper-Vudee and Ndolwa), with one located in Mwembe (see Fig. 3). The major part of the rainfall fell in a time span of only $3 \mathrm{~h}$ (10 a.m. -1 p.m.). Intensities as high as $49 \mathrm{~mm} \mathrm{~h}^{-1}$ were recorded in the valley of Vudee subcatchment (Bangalala village), where also one of the highest total daily amount was observed (Eliza and Mchikatu) (Table 1, Fig. 4). The automatic rain gauges confirm that rainfall in the Mwembe area was considerably less than in the Vudee sub-catchment ( 15 compared to $80-100 \mathrm{~mm} \mathrm{~d}^{-1}$ ). This high spatial variability is common in high intensity rainfall events and can result into flash floods (Foody et al., 2004; Gaume et al., 2004).

\subsection{Runoff}

Water levels were monitored at five points in the catchment, of which four cross-sections had known rating curves. The locations of the discharge measurements are shown in Fig. 1. Only at the weir site the hydrograph could be reconstructed. The pressure transducer at the weir site recorded water levels during the rising limb (every $15 \mathrm{~min}$ ), but was destroyed during the peak discharge. The peak of the water level has been estimated using flood marks. The water levels during the recession limb were recorded by the local observers who took water quality samples at the same time (every $2 \mathrm{~h}$ for 3 days). The observations at the other sites were difficult to quantify, as the structures were either destroyed or severely damaged; however, from the few observations a general estimation of the response time could be estimated. 

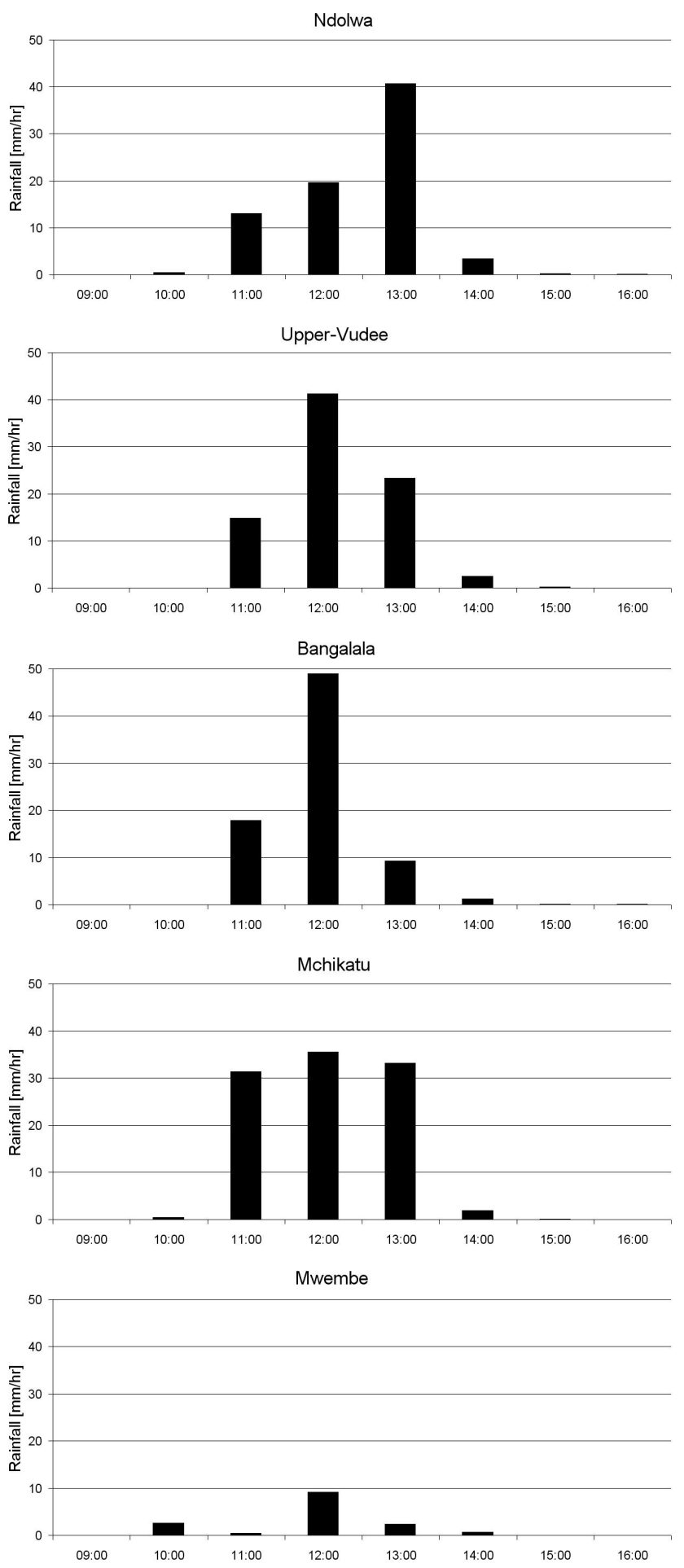

Fig. 4. Hourly rainfall in the Makanya catchment on 1 March 2006.

\subsubsection{Vudee sub-catchment}

The Vudee River at the weir site drains an area of approximately $25.8 \mathrm{~km}^{2}$. The discharge at the weir has been obtained by converting the water level into discharge using different

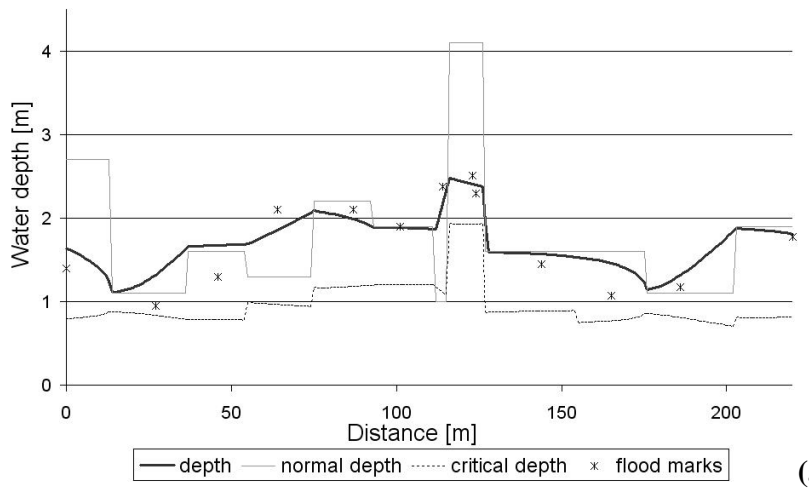

(a)

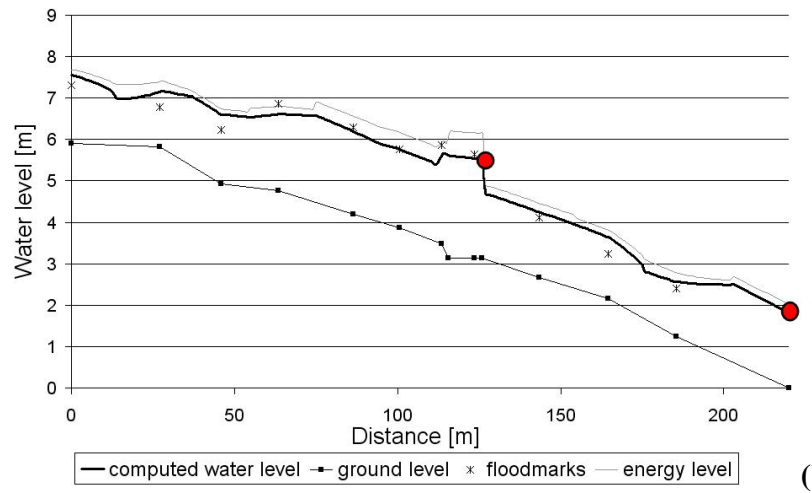

(b)

Fig. 5. (a) Observed flood marks and modelled water levels, normal and critial depths and, (b) observed flood marks and modelled water and energy levels, compared to a fixed reference level.

methods. The compound weir consists of a V-notch and rectangular weir (see Fig. 2). Rating curves for the compound weir were obtained from Hudson (1993), and were applied for water levels below $1.5 \mathrm{~m}$, above which the structure overtops (at about $13 \mathrm{~m}^{3} \mathrm{~s}^{-1}$ ). During this event the structure overtopped and maximum discharge had to be determined by converting the maximum water level to discharge. The maximum water levels upstream and downstream of the weir were obtained by surveying the flood marks. The longitudinal section is shown in Fig. 5, with the ground level and flood marks. Cross sections were measured at 12 locations along the transect. Two techniques have been used to determine the maximum discharge, a) slope-area method, and b) gradually varied flow calculations, which are described below. Similar reconstruction of the maximum discharge was done by Rico et al. (2001) and Gaume et al. (2003, 2004).

\section{Slope-area method}

If we assume that near the peakflow the temporal deviations are small $(\delta h / \delta t=0)$ and, moreover, that the gradient of the cross-sectional area is small, then Manning's equation for permanent flow may be applied (Acrement and Schneider, 1990):

$Q_{\max }=\frac{1}{n} A R^{2 / 3} i^{1 / 2}$ 
The energy slope $(i)$ is assumed to be similar to the bed slope ( $s$, an average of 3\%; see Fig. 5b). Only the section upstream of the weir has been used for the calculations as it is seen as a uniform stretch of the river. It is assumed that during permanent flow, the flow-through area $\left(A, \mathrm{~m}^{2}\right)$ and hydraulic radius $(R, \mathrm{~m})$ can be obtained from the flood marks (assuming this is indicating the maximum water level). The roughness coefficient (Manning's $n, \mathrm{~s} \mathrm{~m}^{-1 / 3}$ ) is assumed 0.05 (combination of cobbles and boulders (Acrement and Schneider, 1990). The discharge estimates ranges between 30 and $60 \mathrm{~m}^{3} \mathrm{~s}^{-1}$, with an average of $47 \mathrm{~m}^{3} \mathrm{~s}^{-1}$ (depending on the distance and cross sections selected). Obviously, the cross-sectional area is not uniform, hence, the method for gradually varied flow needs to be used.

\section{Gradually varied flow calculation}

The second method used for estimating the maximum discharge was to simulate the water depth for the entire cross section using backwater computation (Chow, 1959; French, 1985). For this purpose, the complete river reach upstream and downstream of the weir has been used. Two boundary conditions are needed, where the water depth is fixed: downstream of the reach and downstream of the weir (Fig. 5b). The boundary condition downstream of the weir is needed as an internal boundary because critical flow occurs at this point, indicated by a circle in Fig. 5b. In the rest of the reach the flow is sub-critical during the maximum discharge. The following equations have been used to estimate the change of water depth $(d y / d x)$ in the longitudinal section $(d x$ of $1 \mathrm{~m}$ has been applied).

$\frac{d y}{d x}=s \frac{\left(1-y_{N} / y\right)^{N}}{\left(1-y_{c} / y\right)^{M}}$

with the actual depth $(y, \mathrm{~m})$ and two constants related to Manning's formula ( $N$ and $M$ are 3.33 and 3, respectively; Chow, 1959). The normal depth $\left(y_{N}, \mathrm{~m}\right)$ is defined by Eqs. (3)-(5). The water depth approaches the normal depth in a uniform section of the river. Manning's equation is used for the normal depth

$A R^{2 / 3}=n \frac{Q_{\text {est }}}{s^{1 / 2}}$

where $A$ and $R$ are functions of $y_{N}$ and $Q_{\text {est }}$ is the estimated discharge. Here we simplified the measured cross sections as a trapezium, between two measuring points the cross sections are assumed to be uniform, the following equations apply for $A$ and $R$ :

$$
\begin{aligned}
& A=(b+z) y_{N} \\
& R=\frac{A}{b+2 \sqrt{y_{N}^{2}+z^{2}}}
\end{aligned}
$$

where $b$ is the bottom width $(\mathrm{m})$ and $z$ is the slope of the banks.

The critical depth $\left(y_{c}, \mathrm{~m}\right)$ is the depth with the critical velocity (see Eq. 6).

$y_{c}=\left(\frac{(Q / B)^{2}}{g}\right)^{1 / 3}$

where $B$ is the width of the cross section.

Figure 5a shows the modelled water depth compared to the observed flood marks using $Q_{\text {est }}=32 \mathrm{~m}^{3} \mathrm{~s}^{-1}$ for the estimated discharge. The flood mark points do not fully agree with the backwater curve calculations, which can be explained by the fact that the flood marks not necessarily mark the highest water level. Branches and sticks may be pushed up, higher than the actual water level when the water hits obstacles (possibly reaching the energy level). In addition, the cross sections are schematised as trapeziums and do not incorporate floodplains and trees obstructing the flow, sudden changes in the cross sections are also not incorporated. Figure 5a shows a relatively good fit between observed and computer water depth, considering the accuracy of the flood mark observations. Figure $5 b$ shows the computed energy (thin line) and water level (thick line) compared to a fixed reference level.

Figure 5a also shows the normal and critical water depth, the jumps in the calculated normal and critical water depth is due to the assumption of uniform cross sections between the measuring points. Throughout the profile the normal water depth is above the critical water depth, and the water depth approaches asymptotically the normal depth, calculating from downstream to upstream. Only just upstream of the weir site the normal depth is lower than the critical depth, which explains the hydraulic jump.

\section{Hydrograph}

In the hydrograph, the discharge exceeding the capacity of the compound weir but below the peak discharge has been interpolated by a straight line (above the dashed line in Fig. 6). Between one to two hours after the rainfall started (rainfall recorded at 11 a.m., fell between 10 a.m. and 11 a.m.), the discharge started to increase $\left(7 \mathrm{~m}^{3} \mathrm{~s}^{-1}\right.$ was recorded at $12 \mathrm{p} . \mathrm{m}$.). The maximum discharge was recorded at 12:45 p.m., less than $3 \mathrm{~h}$ after the start of the rains. The recession is as quick as the rise, reducing a peak flow of 32 to $4 \mathrm{~m}^{3} \mathrm{~s}^{-1}$ within one hour.

\subsubsection{Makanya catchment}

The two flume sites draining two small catchments, Ndunduve and Mchikatu in the Bangalala area $\left(2\right.$ and $5 \mathrm{~km}^{2}$, respectively, see for locations Fig. 1), had the quickest time of concentration, with the flumes overtopping at 9:55 a.m. and 10:15 a.m., respectively, responding immediately to the rainfall. The site at Maji ya Chome, draining the Chome sub-catchment with approximately the same drainage area as 


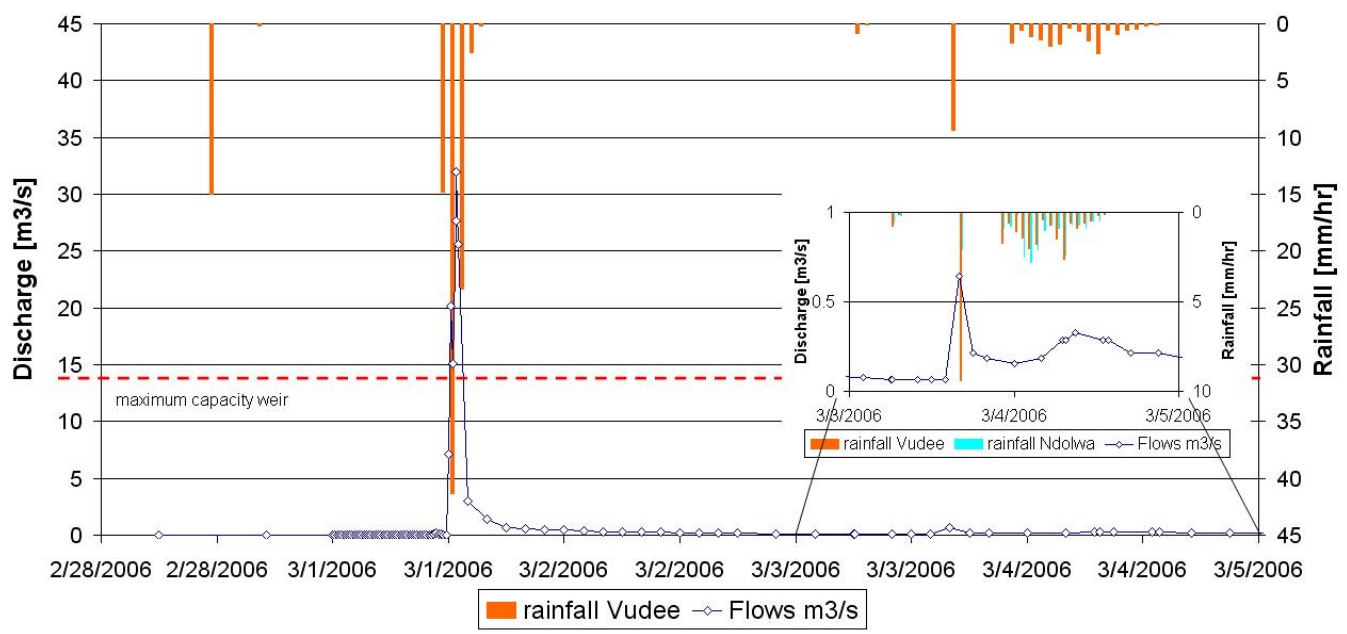

Fig. 6. Hydrograph observed at the Vudee weir on 1 March 2006.

the Vudee sub-catchment, also recorded large flows starting at 12 p.m., overflowing and damaging the gauging structure. The gauge at Mgwasi at the outlet of the Makanya catchment (drainage area of $260 \mathrm{~km}^{2}$ ), located at a road bridge, recorded overtopping at 12:15 p.m., not much later than the occurrence of the peak flows at the sub-catchments. Concentration times at the smallest scale were almost instantaneous, at the subcatchment scale a delay of $1-2 \mathrm{~h}$ was observed, whereas the start of the rise of flood at the sub-catchment scale and the catchment scale did not differ substantially.

\subsection{Water quality}

Water samples have been taken at the main monitoring site (Vudee weir) and upstream of the confluence between the Upper-Vudee and Ndolwa tributaries. The samples collected at the three sites at first had a very high content of fine material (suspended load; diameters between $45-100 \mu \mathrm{m}$ ). This indicates a significant contribution of Hortonian overland flow during the beginning of the flood. The small particles can be explained by the very dry antecedent conditions, where fine particles are deposited on the top-soil by wind erosion and subsequently washed out by the first big rainfall event. Samples collected after the flood peak also contained significant amounts of sediment, but less fine particles.

Samples have been analysed for the major cations and anions (i.e. $\mathrm{Ca}^{2+}, \mathrm{Mg}^{2+}, \mathrm{Na}^{+}, \mathrm{K}^{+}, \mathrm{SO}_{4}^{2-}, \mathrm{Cl}^{-}, \mathrm{F}^{-}$and dissolved silica, see for methods of analysis; Mul et al., 2008). The water quality during the flood event shows a typical pattern, except for potassium they all start with a low concentration at the peak of the event followed by a slow increase until a maximum value (Fig. 7). This is consistent with expectations, whereby the concentrations are diluted with the surface runoff (generally with lower concentrations). Potassium shows an inverse pattern, high concentrations during the peak flows, what can be attributed to the fact that direct surface runoff picks up potassium concentrations, which indicates a significant amount of surface runoff. Similar patterns have been observed by Winston and Criss (2002); Didszun and Uhlenbrook (2008). The rainfall event, two days after the extreme event caused a decrease of the concentrations in the Upper-Vudee and at the weir, but less in the Ndolwa. This is consistent with the rainfall at 4 p.m., which predominantly fell in Upper-Vudee $\left(9.4 \mathrm{~mm} \mathrm{~h}^{-1}\right.$ compared to $2.1 \mathrm{~mm} \mathrm{~h}^{-1}$ in Ndolwa).

\subsection{Hydrograph separation}

Chemical hydrograph separation is a method to define the origin and composition of the runoff during floods (e.g. Uhlenbrook et al., 2002). This method is based on the mixing of two or more water types with known and distinct hydrochemical characteristics, where the ratio of mixing determines the concentrations in the stream. Chemical hydrograph separation is predominantly done to separate sub-surface and surface runoff (runoff source areas). The collected hydrochemical data was used for hydrograph separation of surface and sub-surface contributions. Mul et al. (2008) showed that dissolved silica is the most appropriate parameter to separate between surface and sub-surface runoff. Unfortunately, the water quality data on dissolved silica is not suitable to do this analysis (the suspended solids affected the dissolved silica concentrations). A previous flood event in the same catchment showed that using EC gave similar results for estimating the groundwater contributions (Mul et al., 2008) and several other studies have used EC as a valuable indicator (Matsubayashi et al., 1993; Caissie et al., 1996; Laudon and Slaymaker, 1997). Figure 8 is the result of EC-based hydrograph separation (end member concentration for groundwater is $300 \mu \mathrm{S} \mathrm{cm}^{-1}$ and for surface runoff $15 \mu \mathrm{S} \mathrm{cm}^{-1}$, similar to rainfall concentrations). It shows that just after the peak of the flood almost $50 \%$ of the runoff is generated 

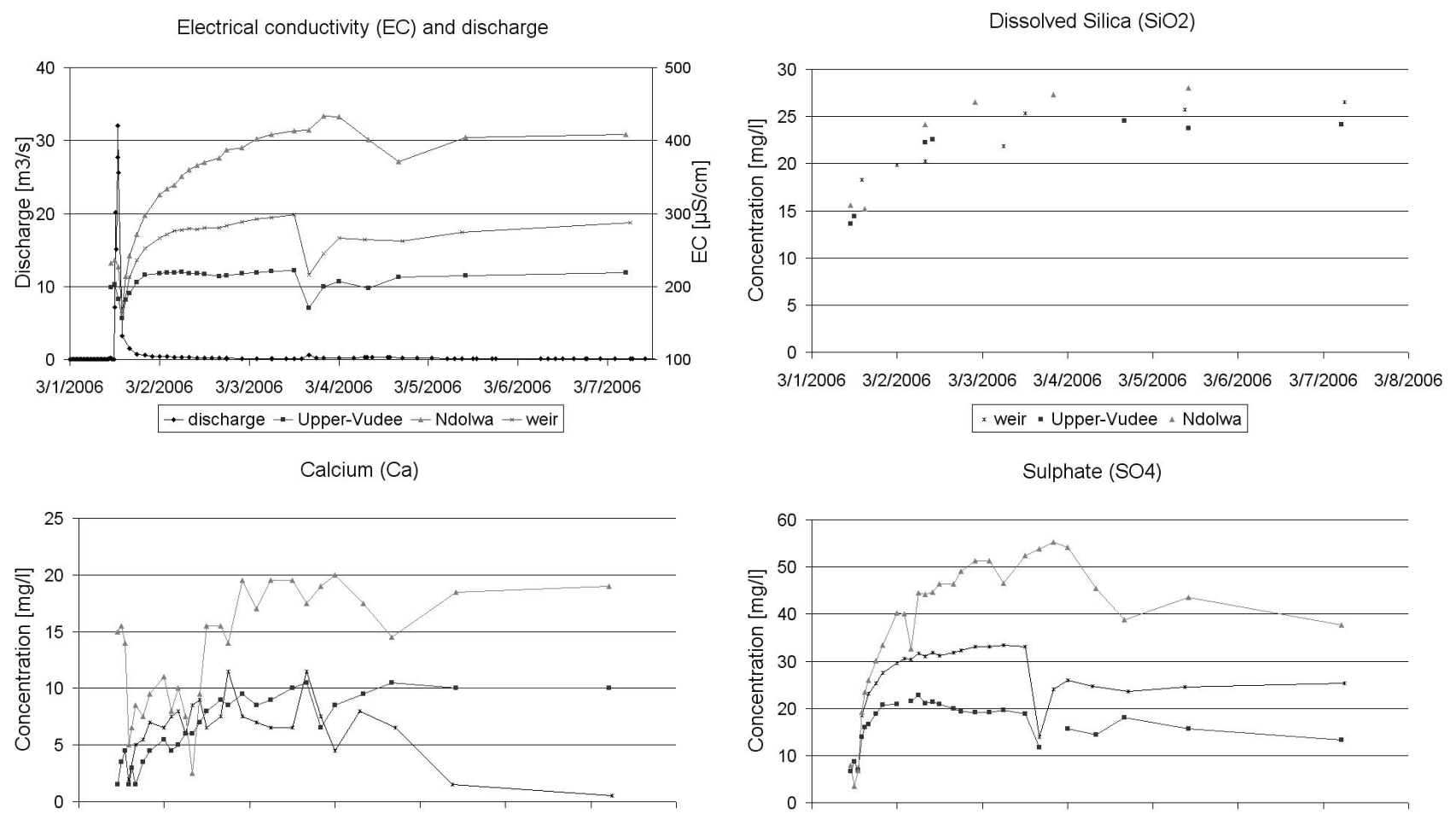

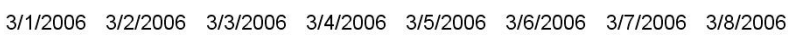
$\rightarrow$ weir - Upper-Vudee $\_$Ndolwa

Magnesium (Mg)

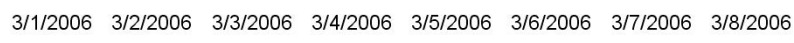

$$
\begin{aligned}
& \rightarrow \text { weir }- \text { Upper-Vudee } ₫ \text { Ndolwa } \\
& \text { Sodium }(\mathrm{Na})
\end{aligned}
$$
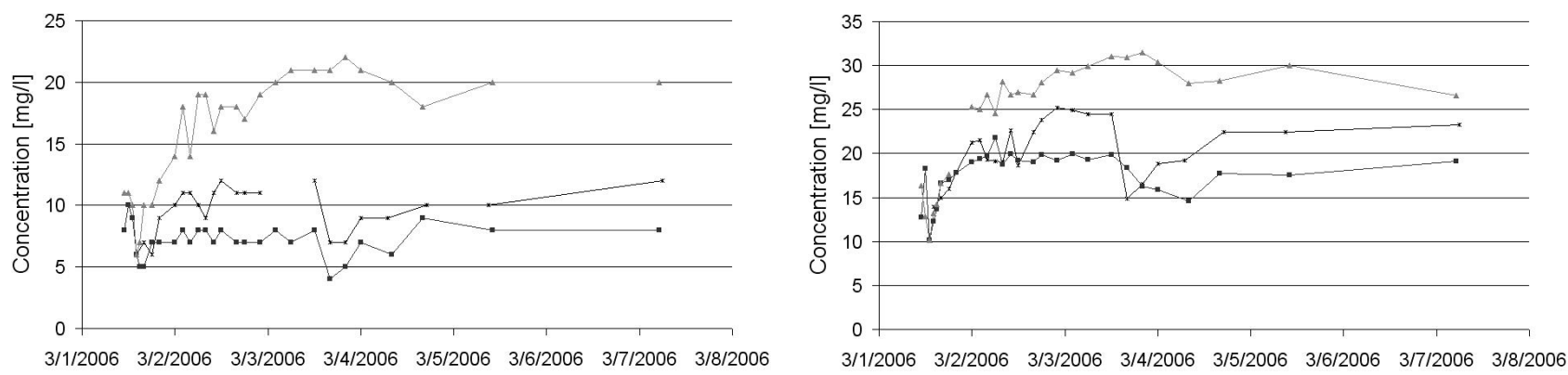
$\rightarrow$ weir - Upper-Vudee $\leftarrow$ Ndolwa

Chloride $(\mathrm{Cl})$
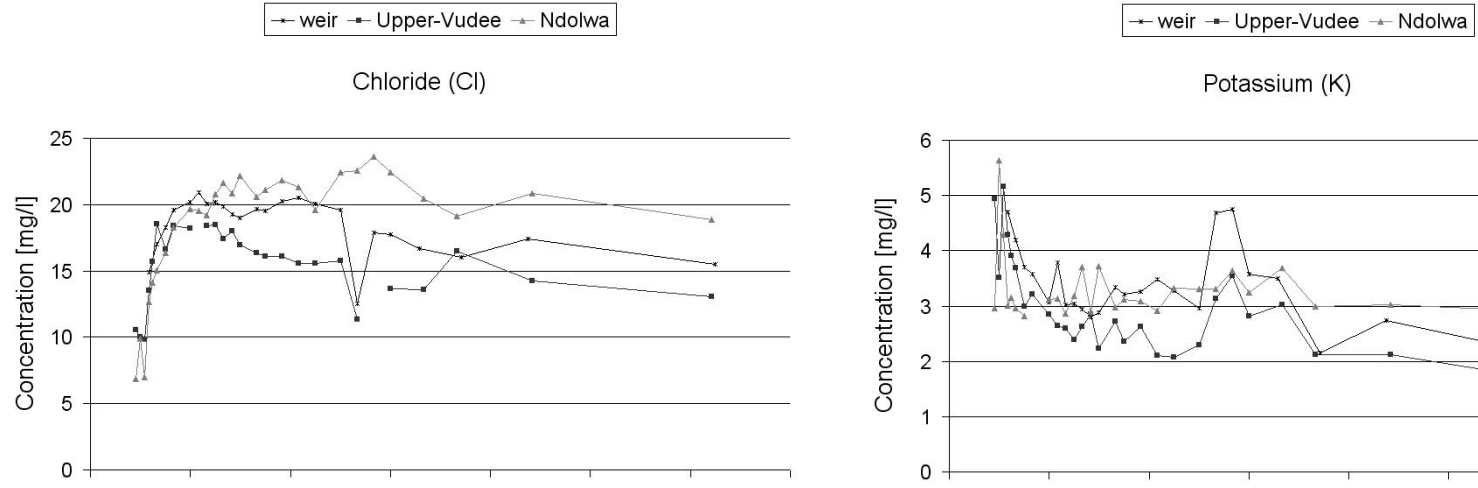

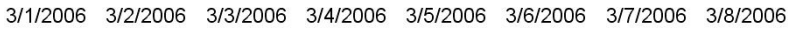
$\rightarrow$ weir - Upper-Vudee $\_$Ndolwa

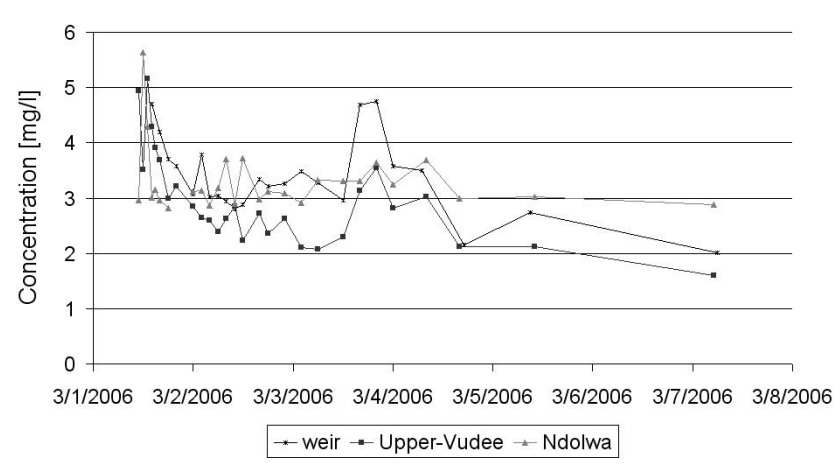

Fig. 7. Hydro-chemical parameters at the Vudee weir during the 1 March 2006 event. 


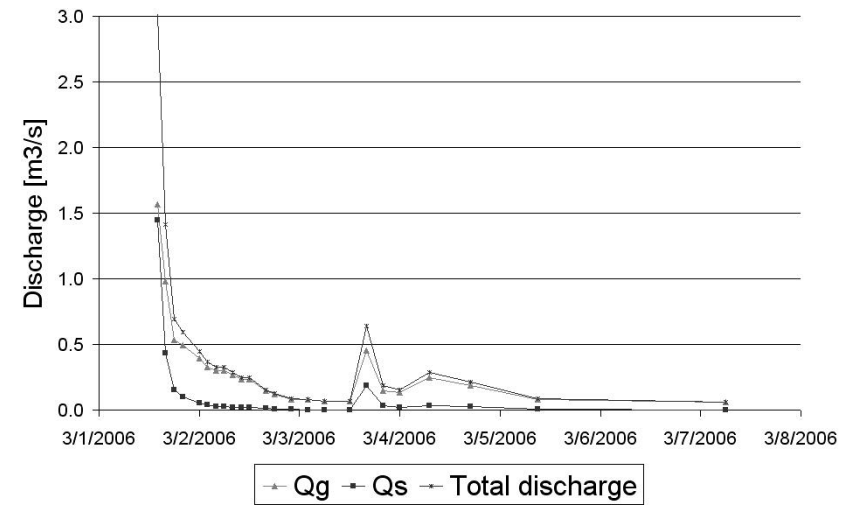

Fig. 8. Hydrograph separation based on EC values for sub-surface $\left(Q_{g}\right)$ and surface runoff $\left(Q_{s}\right)$.

by direct surface runoff, which is also apparent in the high concentration of suspended particles in the samples. Within $6 \mathrm{~h}$ into the recession the major part of the flow is generated by groundwater (Fig. 8). In more studies large groundwater contributions were found during the peak discharge (Frederickson and Criss, 1999; Pinder and Jones, 1969; Sklash and Farvolden, 1979; Wenninger et al., 2008). Although many others also found that with increasing intensity of the storms the event water contribution (surface runoff) also increases (Caissie et al., 1996; Hooper and Shoemaker, 1986; Brown et al., 1999).

The hydrograph sampling at the tributaries started during the peak of the event, at the weir the samples started soon after the peak. Mul et al. (2008) showed that the hydrochemical parameters at the weir are dependent on the runoff contribution from the two sub-catchments which are distinctly different. Therefore, hydrograph separation has been done on the origin of the flood; in other words, from which subcatchment the flood came. In the case of the small flood events in 2005, contribution from surface water was less than $5 \%$, base flow samples from the tributaries were taken as background concentrations for the hydrograph separation (Mul et al., 2008). However, in this event surface water contributions were much higher and the background concentrations of the two sub-catchments could not be used for the hydrograph separation based on the origin. For each time step, concentrations have been obtained at three locations, these concentrations were then used to determine the contribution from each sub-catchment. Figure 9 shows the separation into the origin of the flow based on $\mathrm{EC}, \mathrm{Mg}^{2+}, \mathrm{Na}^{+}$and $\mathrm{SO}_{4}^{2-}$.

The analysis demonstrates that the contribution from Ndolwa (37\% of total catchment area) during this event is in the range between $26-40 \%$ (Fig. 9), which is logical as similar rainfall amounts fell in both sub-catchments. On the other hand, the small second peak on 3 March was generated for the larger part in Upper-Vudee, where $9.4 \mathrm{~mm} \mathrm{~h}^{-1}$ was recorded as compared to $2.1 \mathrm{~mm} \mathrm{~h}^{-1}$ in Ndolwa.

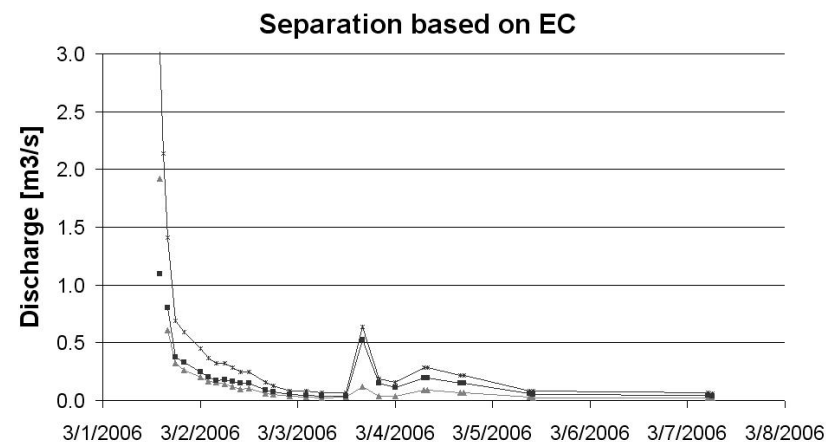

$\begin{array}{llllll}3 / 1 / 2006 & 3 / 2 / 2006 & 3 / 3 / 2006 & 3 / 4 / 2006 & 3 / 5 / 2006 & 3 / 6 / 2006 / 2006\end{array}$

$\rightarrow$ Ndolwa - Upper-Vudee * Total flow
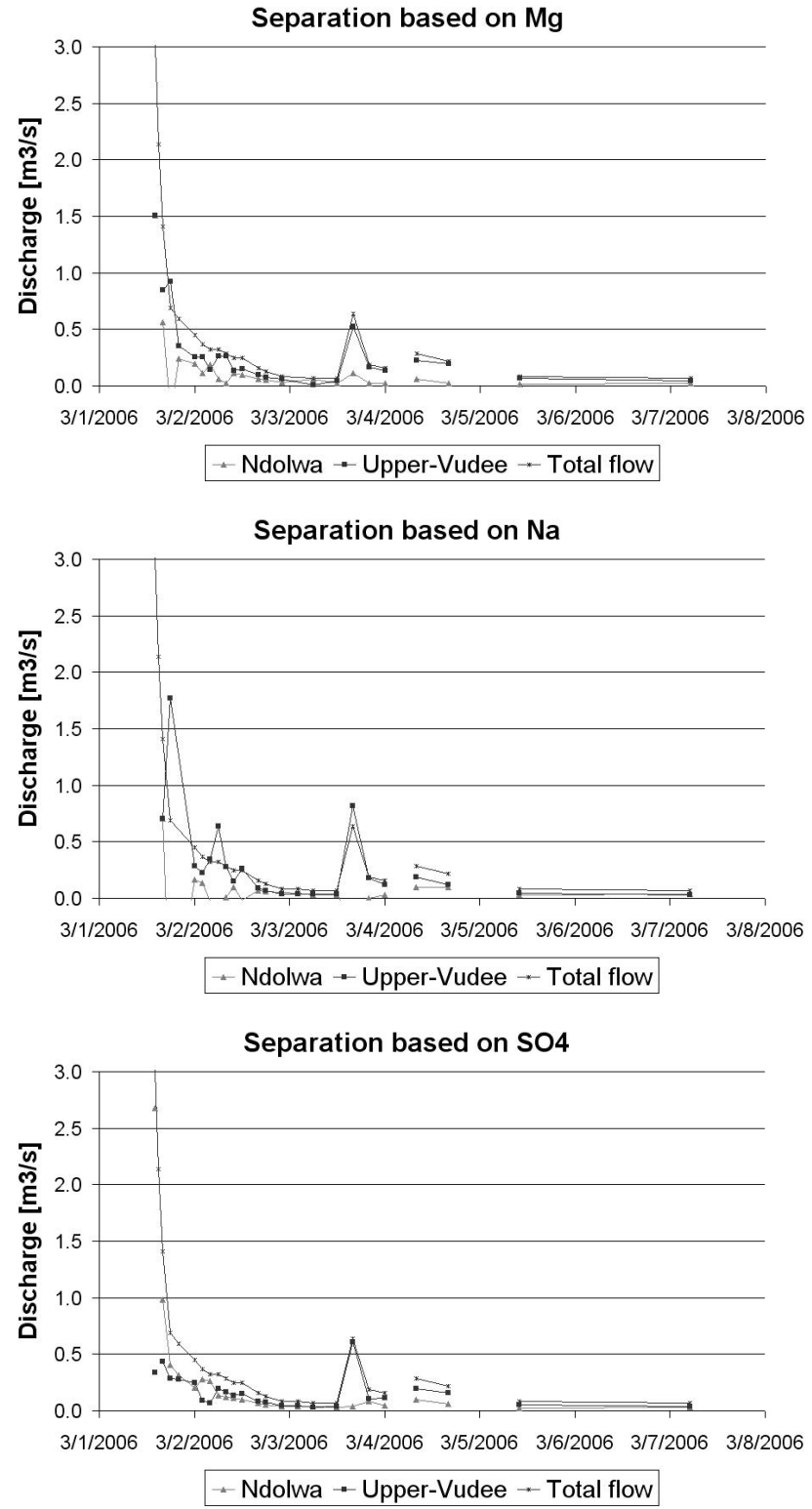

Fig. 9. Hydrograph separation based on $\mathrm{EC}, \mathrm{Mg}^{2+}, \mathrm{Na}^{+}$and $\mathrm{SO}_{4}^{2-}$ for sub-catchment contributions. 


\subsection{Water balance}

At only one location the water balance could be established (Vudee sub-catchment), where the reconstruction of the hydrograph is relatively certain. The total volume of the rainfall in the upper catchment (UpperVudee (area $14.2 \mathrm{~km}^{2}$ ), $82.1 \mathrm{~mm} \mathrm{~d}^{-1}$, Ndolwa (area $8.4 \mathrm{~km}^{2}$ ) $77.5 \mathrm{~mm} \mathrm{~d}^{-1}$, and Mchikatu (area $3.2 \mathrm{~km}^{2}$ ) $102.7 \mathrm{~mm} \mathrm{~d}^{-1}$ ), amounted to $2.15^{*} 10^{6} \mathrm{~m}^{3}$. The volume of runoff observed at the weir site, during the first $24 \mathrm{~h}$ was estimated to $0.19 * 10^{6} \mathrm{~m}^{3}$, which corresponds to $9 \%$ of the rainfall (volume under the hydrograph of Fig. 6; note that the uncertain estimation of the peak discharge does not significantly change the volume as the duration of the peak flow was very short). As the amount of evaporation during the day itself can be assumed less than 5\% of the recorded rainfall $\left(<4 \mathrm{~mm} \mathrm{~d}^{-1}\right)$, the storage in the (upper) catchment should have increased substantially. This is demonstrated by the increase of the base flow observed during the subsequent period, which increased from about $151 \mathrm{~s}^{-1}$ before the flood to $751 \mathrm{~s}^{-1}$ in the subsequent season. The increased storage discharged an approximate $0.54 * 10^{6} \mathrm{~m}^{3}(34 \%$ of the rainfall) in the following season, calculation based on the outflow of a linear reservoir. The balance (57\%) is made up by evaporation in the period following the flood and percolation to the regional groundwater system (Mul et al., 2007). Having a large part of the rainfall contributing to slow processes is not uncommon for flash floods (Gaume et al., 2004; Belmonte and Beltran, 2001), however, $90 \%$ is very high, which indicates that the downstream effects could have been much worse. The uncertainties of this water balance analysis are linked to the assumptions of calculating the different components: i) uniform rainfall distribution in the three upstream areas of the Vudee sub-catchment; ii) the assumption of steady flow at peak discharge and iii) the assumption of a linear reservoir for the base flow calculation.

\section{Conclusions}

During this event a unique data set of an extreme rainfall and flood event was gathered in a meso-scale, semi-arid catchment. The rainfall in Vudee sub-catchment was between 75 and more than $100 \mathrm{~mm} \mathrm{~d}^{-1}$, Mwembe village only recorded $15 \mathrm{~mm} \mathrm{~d}^{-1}$, even though it lies less than $10 \mathrm{~km}$ from the centre of the storm. Furthermore, the meteorological station in Same (approximately $15 \mathrm{~km}$ away), with the longest record available, observed no rainfall at all during this event. Consequently, spatial variability of the rainfall during this event was very high and not directly related to topographic features.

Reconstruction of the flow at the weir shows that the peak flow was $32 \mathrm{~m}^{3} \mathrm{~s}^{-1}$, which was reached within $1 \mathrm{~h}$ after the onset of the rainfall. Only $10 \%$ of the rainfall passed through the weir during the event, the remainder was stored in the upstream catchment, and discharged as base flow during the consecutive season. Hydrograph separation shows that, during the peak flows, $50 \%$ of the flow is contributed by direct surface runoff, followed by a recession, mainly fed by the groundwater reservoir (>90\%). During the flood event contributions from the two sub-catchments, Upper-Vudee and Ndolwa are equivalent to their respective size. During the smaller flood event on 3 March contribution is mainly from Upper-Vudee, where the larger part of the rain fell (9.4 compared to $2.1 \mathrm{~mm} \mathrm{~h}^{-1}$ in Ndolwa). The response time of the catchment at all scales (upto $300 \mathrm{~km}^{2}$ ) is less than two hours. The flood caused a lot of damage to the downstream village (five houses were destroyed, the main road between Dar es Salaam and Arusha was blocked for several hours and many of the plots in the spate-irrigation system were affected), even though upstream storage reduced the flows considerably.

Extreme rainfall intensities and short concentration times characterise this event. These characteristics enhance the unpredictable nature of such big floods at the outlet of the catchment. Highly localised rainfall can cause significant damage in the lower parts of the catchment, the short response time leaves little time for the residents to vacate the floodplains and bring their belongings to safe areas. This paper concludes that by using the assumption of uniform spatial distribution of rainfall, the predicted runoff can easily be over- or underestimated. However, in sub-Saharan Africa the extent of the rainfall network is not adequate to capture all the spatial rainfall variability and, therefore, compromises the accuracy of the runoff predictions.

Acknowledgements. The work reported here was undertaken as part of the Smallholder System Innovations in Integrated Watershed Management (SSI) Programme funded by the Netherlands Foundation for the Advancement of Tropical Research (WOTRO), the Swedish International Development Cooperation Agency (Sida), the Netherlands Directorate-General of Development Cooperation (DGIS), the International Water Management Institute (IWMI) and UNESCO-IHE Institute for Water Education. Implementation on site was assisted by the Soil-Water Management Research Group (SWMRG), Sokoine University of Agriculture, Tanzania.

Edited by: A. Montanari

www.hydrol-earth-syst-sci.net/13/1659/2009/ 


\section{References}

Acrement, G. J. and Schneider, V. R.: Guide for selection Manning's roughness coefficients for natural channels and floodplains, United States Geological Survey Water-supply paper 2339, 37 pp., 1990.

Belmonte, A. C. and Beltran, F. S.: Flood events in Mediterranean ephemeral streams (ramblas) in Valencia region, Spain, Catena, 45, 229-249, 2001.

Bhatt, Y., Bossio, D., Enfors, E., Gordon, L., Kongo, V., Kosgei, J. R., Makurira, H., Masuki, K., Mul, M., and Tumbo, S. D.: Smallholder system innovations in integrated watershed management (SSI): Strategies of water for food and environment security in drought-prone tropical and subtropical agro-ecosystems, IWMI working paper 109, IWMI Colombo, Sri Lanka, 59 pp., 2006.

Blume, T., Zehe, E., Reusser, D. E., Iroume, A., and Bronstert, A.: Investigation of runoff generation in a pristine, poorly gauged catchment in the Chilean Andes I: A multi-method experimental study, Hydrol. Process., 22, 3676-3688, 2008.

Brown, V. A., McDonnell, J. J., Burns, D. A., and Kendall, C.: The role of event water, a rapid shallow flow component, and catchment size in summer stormflow, J. Hydrol., 217, 171-190, 1999.

Caissie, D., Pollock, T. L., and Cunjak, R. A.: Variation in stream water chemistry and hydrograph separation in a small drainage basin, J. Hydrol., 178, 137-157, 1996.

Calder, I. R.: The Blue Revolution, Earthscan Publications, London, 192 pp., 1999.

Chow, V. T.: Open-channel hydraulics, McGraw-Hill Book Company, 680 pp., 1959.

Didszun, J. and Uhlenbrook, S.: Scaling of dominant runoff generating processes: Nested catchments approach using multiple tracers, Water Resour. Res., 44, W02410, doi:10.1029/2006WR005242, 2008.

Enfors, E. and Gordon, L.: Analyzing resilience in dryland agroecosystems: a case study of the Makanya catchment in Tanzania over the past 50 years, Land Degrad. Dev., 18, 680-696, 2007.

Foody, G. M., Ghoneim, E. M., and Arnell, N. W.: Predicting locations sensitive to flash flooding in an arid environment, J. Hydrol., 292, 48-58, 2004.

Frederickson, G. C. and Criss, R. E.: Isotope hydrologic and residence times of the unimpounded Meramec River Basin, Missouri, Chem. Geol., 157, 303-317, 1999.

French, R. H.: Open-channel hydraulics, McGraw-Hill Book Company, 705 pp., 1985.

Gaume, E., Livet, M., and Desbordes, M.: Study of the hydrological processes during the Avene river extraordinary flood (South of France): 6-7 October 1997, Phys. Chem. Earth, 28, 263-267, 2003.

Gaume, E., Livet, M., Desbordes, M., and Villeneuve, J.-P.: Hydrological analysis of the river Aude, France, flash flood on 12 and 13 November 1999, J. Hydrol., 286, 135-154, 2004.

Guzman J. A. and Chu, M. L.: SPELL-Stat statistical analysis program, Universidad Industrial de Santander, Colombia, 142 pp., 2003.

Hooper, R. P. and Shoemaker, C. A.: A comparison of chemical and isotopic hydrograph separation, Water Resour. Res., 22, 14441454, 1986.

Hudson, N. W.: Field measurement of soil erosion and runoff, FAO 68, Rome, 139 pp., 1993.
Laudon, H. and Slaymaker, O.: Hydrograph separation using stable isotopes, silica and electrical conductivity: an alpine example, J. Hydrol., 201, 82-101, 1997.

Makurira, H., Mul, M. L., Vyagusa, N. F., Uhlenbrook, S., and Savenije, H. H. G.: Evaluation of Community-Driven Smallholder Irrigation in South Pare Mountains, Tanzania; A case study of Manoo micro-dam, Phys. Chem. Earth, 32, 1090-1097, 2007.

Mason, S. J., Waylen, P. R., Mimmach, G. M., Rajaratnam, B., and Harrison, J. M.: Changes in extreme rainfall events in South Africa, Climate Change, 41, 249-257, 1999.

Matsubayashi, U., Vealsquez, G. T., and Takagi, F.: Hydrograph separation and flow analysis by specific electrical conductance of water, J. Hydrol., 152, 179-199, 1993.

Mazvimavi, D.: Estimation of flow characteristic of ungauged catchments, case study in Zimbabwe, $\mathrm{PhD}$ dissertation, Wageningen University, The Netherlands, 176 pp., 2003.

Mul, M. L., Savenije, H. H. G., Uhlenbrook, S., and Voogt, M. P.: Hydrological assessment of Makanya catchment in South Pare Mountains, semiarid northern Tanzania, Climate Variability and Change-Hydrological Impacts (Proceedings of the Fifth FRIEND World Conference held at Havana, Cuba, November 2006), IAHS Publ., 308, 37-43, 2006.

Mul, M. L., Mutiibwa, R. K., Foppen, J. W. A., Uhlenbrook, S., and Savenije, H. H. G.: Identification of groundwater flow systems using geological mapping and chemical spring analysis in South Pare Mountains, Tanzania, Phys. Chem. Earth, 32, 1015-1022, 2007.

Mul, M. L., Mutiibwa, R. K., Uhlenbrook, S., and Savenije, H. H. G.: Hydrograph separation in the South Pare Mountains, Phys. Chem. Earth, 33, 151-156, 2008.

Mul, M. L.: Understanding hydrological processes in an ungauged catchment in sub-Saharan Africa, PhD dissertation, UNESCOIHE, Delft, the Netherlands, 130 pp., 2009.

Mwamfupe, D. G.: The Role of Non-Farm Activities in Household Economies: A Case Study of Pangani River Basin, Tanzania, in: Water Resour. Manag., the Case of the Pangani River Basin, edited by: Ngana, J. O., Issues and Approaches, Dar Es Salaam, 39-47, 2002.

Pinder, G. F. and Jones, J. F.: Determination of the ground-water component of peak discharge from the chemistry of total runoff, Water Resour. Res., 5, 438-445, 1969.

Rico, M., Benito, G., and Barnolas, A.: Combined Palaeoflood and rainfall assessment of mountain floods (Spanish Pyrenees), J. Hydrol., 245, 59-72, 2001.

Rockström, J., Folke, C., Gordon, L., Hatibu, N., Jewitt, G., Penning de Vries, F., Rwehumbiza, F., Sally, H., Savenije, H., and Schulze, R.: A watershed approach to upgrade rainfed agriculture in water scarce regions through water systems innovations: an integrated research initiative on water for food and rural livelihoods in balance with ecosystem functions, Phys. Chem. Earth, 29, 1109-1118, 2004.

Sandström, K.: Forest and Water - Friends or Foes, Hydrological implications of deforestation and land degradation in semi-arid Tanzania, PhD dissertation, University of Linköping, Linköping, Sweden, 182 pp., 1995.

Sklash, M. G. and Farvolden, R. N.: The role of groundwater in storm runoff, J. Hydrol., 43, 45-65, 1979.

Sivapalan, M., Takeuchi, K., Franks, S. W., Gupta, V. K., Karam- 
biri, H., Lakshmi, V., Liang, X., McDonnell, J. J., Mendiondo, E. M., O'Connell, P. E., Oki, T., Pomeroy, J. W., Schertzer, D., Uhlenbrook, S., and Zehe, E.: IAHS Decade on predictions in ungauged basins (PUB), 2003-2012: Shaping an exciting future for the hydrological sciences, Hydrolog. Sci. J., 48, 857-880, 2003.

SUA: Smallholder system innovations in integrated catchment management: The Profile of the Chome-Makanya Catchment and Pangani river basin in Tanzania, in: Strategies of water for food and environmental security in drought prone tropical and subtropical agro-ecosystems (Tanzania and South Africa), SSI progress report No. 1, 190 pp., 2003.

URT (The United Republic of Tanzania): 2002 Population and Housing Census, Volume IV, District profile, Same, Central Census Office, National Bureau of Statistics, President's Office, Planning and Privatisation, Dar Es Salaam, 2004.
Uhlenbrook, S., Frey, M., Leibundgut, C., and Maloszewski, P.: Hydrograph separations in a mesoscale mountainous basin at event and seasonal timescales, Water Resour. Res., 38, 1096, doi:10.1029/2001WR000938, 2002.

Valimba, P.: Rainfall variability in southern Africa, its influences on streamflow variations and its relationships with climatic variations, PhD dissertation, Rhodes University, South Africa, 217 pp., 2004.

Wenninger, J., Uhlenbrook, S., Lorentz, S., and Leibundgut, Ch.: Identification of runoff generation processes using combined hydrometric, tracer and geophysical methods in a headwater catchment in South Africa, Hydrolog. Sci. J., 53, 65-80, 2008.

Winston, W. E. and Criss, R. E.: Geochemical variations during flash flooding, Meramec River basin, May 2000, J. Hydrol., 265, 149-163, 2002. 